\title{
Development of an efficient and sustainable energy storage system by hybridization of compressed air and biogas technologies (BIO-CAES)
}

\author{
Bernardo Llamas $^{\mathrm{a}, *}$, Marcelo F. Ortega ${ }^{\mathrm{a}}$, Gabriel Barthelemy ${ }^{\mathrm{a}}$, Ignacio de Godos ${ }^{\mathrm{b}, \mathrm{c}}$, \\ F. Gabriel Acién ${ }^{\mathrm{d}}$ \\ a Universidad Politécnica de Madrid, ETSI Minas y Energía, Alenza 4, 28003 Madrid, Spain \\ ${ }^{\mathrm{b}}$ School of Forestry, Agronomic and Bioenergy Industry Engineering (EIFAB), University of Valladolid, Campus Duques de Soria, Soria, Spain \\ ${ }^{\mathrm{c}}$ Institute for Sustainable Processes, University of Valladolid, 47011 Valladolid, Spain \\ ${ }^{\mathrm{d}}$ Universidad de Almería, Departamento de Ingeniería Química, Ctra. De Sacramento s/n. La Cañada de San Urbano, 04120 Almería, Spain
}

\section{A R T I C L E I N F O}

\section{Keywords:}

Energy storage

Compressed air energy storage

Biogas

Technology hybridization

Renewable storage

Renewable energy

\begin{abstract}
A B S T R A C T
The future electricity generation model will require the integration of intermittent renewable sources. For that, the development of new efficient and sustainable energy storage technologies is mandatory. One of the most promising technologies is the utilization of compressed air energy storage (CAES). However, this technology has a limitation related with the management of the heat generated in the compression stage. In this study it is proposed the integration of a CAES system together with an anaerobic digester, which will use the generated heat, supporting the production and storage of biogas as chemical storage of energy. The latter will be used in the air expansion stage to maximize the efficiency of the overall process. In this way, a new energy storage technology by hybridization of BIOgas and CAES is achieved: BIO-CAES technology.
\end{abstract}

\section{Introduction}

In the fight against climate change, the power generation model is addressing a profound transformation in the use of non-fossil primary energy sources [34]. The European Union continues to promote a generation model based on the minimization of emissions of pollutants and especially of $\mathrm{CO}_{2}[8,17,36]$ and, where renewable energy is promoted $[21,20]$. The promotion of renewable energy sources such as solar or wind will undoubtedly contribute to the reduction of emissions from the generation of electricity. On the contrary, its low load factor derived from its intermittency [53], forces an expensive backup system to ensure security of supply [22].

In order to make efficient use of renewable energy (solar and wind), energy storage technologies [48] are considered to guarantee the supply of electricity based on these sources and that allows to manage significant amounts of energy [2]. Among the technologies considered, and in spite of the strong boom in chemical storage, mechanical energy storage [28] continues to occupy the first alternative, where Pumped Hydroelectric Storage (PHS) stands out [33,39]. On the same hand, Compressed Air Energy Storage (CAES) emerges as a reliable technology for large amount of energy storage systems [44,10]. Although this technology has two industrial experiences [13,14,46], its implementation has been limited by the exploratory risk of the subsurface and lower energy efficiency compared to Pumped Hydroelectric Storage $[32,11,39]$. However, CAES investment cost is lower than PHS [47] with similar energy storage capacity [41]. Several According to these authors, several geological formations would be suitable to store energy by means of compressed air.

In order to increase the efficiency of the system, recently different compression-expansion cycles, based on adiabatic principles where the thermal energy generated in the compression process is stored and arranged in the compressed air expansion process, have been considered [52]. This process increases the efficiency of the system reducing the consumption of fossil fuels and, therefore, $\mathrm{CO}_{2}$ emissions [70]. To reduce the handicaps of conventional CAES, different approaches have been considered such as reducing the target depth of the storage cavities [43] or the hybridization of energy storage technologies, such as the integration of CAES and hydrogen [63], and others [3,19,58,4].

In the present work, it is considered a form of technology integration, based on the hybridization of shallow systems of compressed air storage in the subsurface (mini-CAES; [43] and the production of biogas $[31,51]$, as a system for harnessing thermal energy [30,71] and for its ability to store energy chemically in the form of biogas: Anaerobic digestion is a process that allows the generation of energy: 100-150 kWh per ton of organic matter [9]. However, this value could be enhanced using and external source of thermal energy, since in conventional

\footnotetext{
* Corresponding author.

E-mail address: bernardo.1lamas@upm.es (B. Llamas).
} 


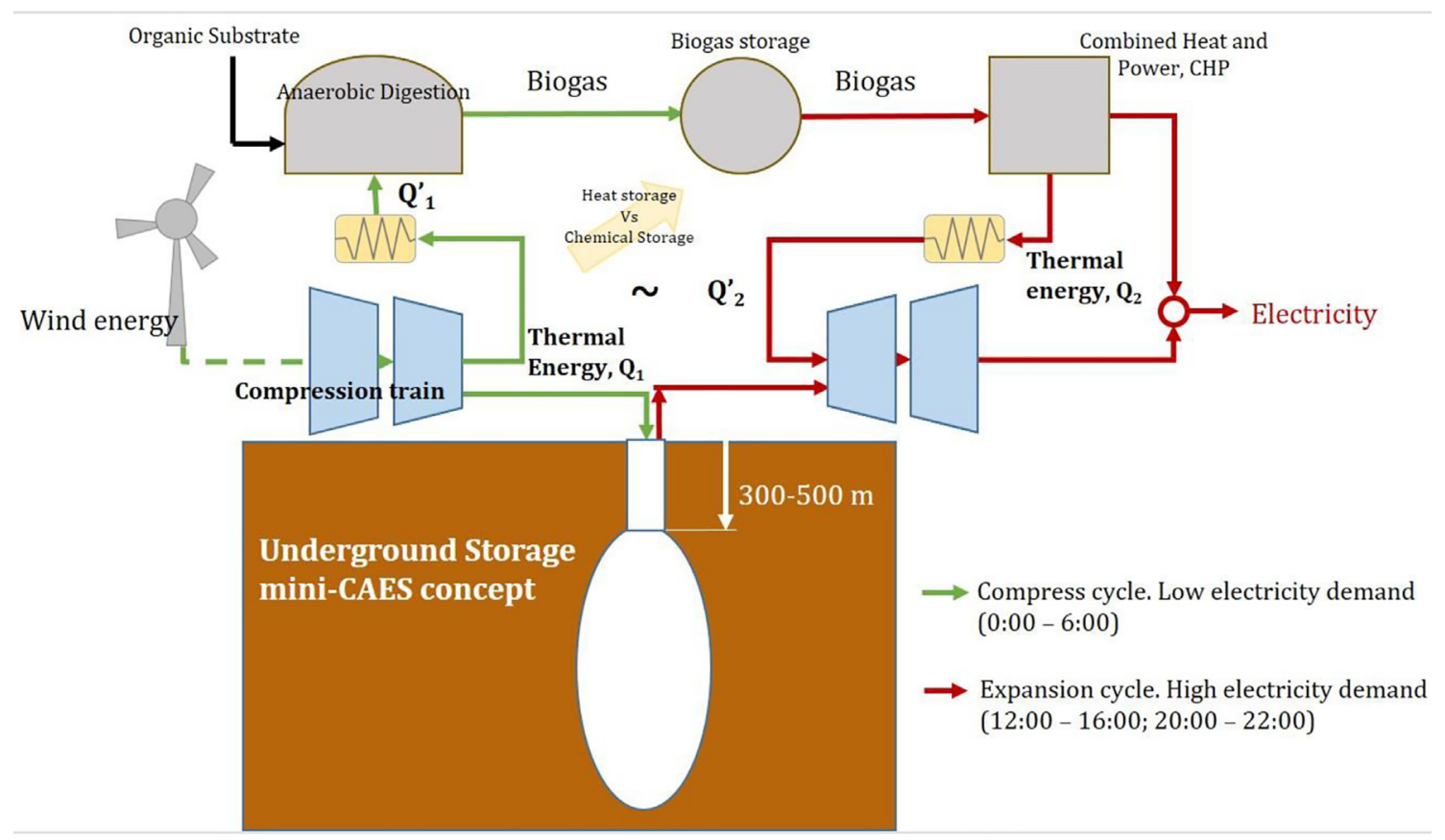

Fig. 1. mini-CAES concept and biogas hybridization as a reliable technology to store renewable energy.

anaerobic installations a fraction of produced biogas is consumed in heating the digester [5].

Anaerobic digestion is based on the degradation of the organic matter through microorganisms at different temperatures, two main scenarios being considered such as mesophilic $\left(35^{\circ} \mathrm{C}\right)$ and thermophilic $\left(55^{\circ} \mathrm{C}\right)[45]$. The energy required to maintain the temperature during the anaerobic digestion is proposed to be supplied from the CAES compression stage, thus allowing a direct use of the heat generated at low temperature, enhancing the production of biogas and efficiency of the overall process. Although CAES systems will provide an intermittent heat supply, concentrated in hours of compression, digester thermostatation is possible by means of a medium temperature buffer tank. With a methane composition of between 50 and $70 \%$ by volume $[64,29]$, this fuel may be stored [68] for use its during the expansion process of stored compressed air (Fig. 1).

In the expansion phase, the biogas obtained is used as fuel for generator sets in a Combined Heat and Power application (CHP) $[65,38]$, where the electrical energy generated is injected into the electric network at the highest demand periods. At the same time, the thermal energy released is added to the compressed air to increase its enthalpy, so it increases the power of the expansion process [16], upgrading the overall energy efficiency of the cycle.

This study evaluates the conditions for hybridization of an anaerobic digester as a strategy to manage the heat generated in the compression process. The research work is completed with the evaluation of electric power generation in the process of expanding compressed air and, combustion of biogas (heat and electricity generation). The storage system based on BIO-CAES technology will be $100 \%$ renewable, with high efficiency of the whole system.

\section{Material and methods}

\subsection{Train of compression and underground cavity conditions}

The process developed is based on the technology of CAES, as a technology already implemented in an industrial plant [41]. However, the main handicap of this technology is related with its low efficiency and, in particular, on the management of thermal energy. The determination of the train of compression, and the compression range, is performed on the formulation described in Llamas et al. [43], where the depth of the cavity (p) is related to the maximum pressure, by Eq. (1).

$P_{\max }=0.18 \hat{\mathrm{A}} \cdot p$

Eq. (1). Maximum Operation Pressure in a Storage Cavity Underground

The calculations performed in the present study, considers a cavity of $20,000 \mathrm{~m}^{3}$ and $100 \mathrm{~m}$ deep (roof of the cavity). This case study would be suitable for the integration of both technologies under consideration and, it would fit the requirements needed for a wind farm (with a capacity of up to $20 \mathrm{MW}$ ). So the maximum operation pressure would be 18 bar, whereas the minimum pressure would be 9 bar.

According to previous characterization of sites in the basin BasqueCantabrian [42] outcrop saline domes may be considered as a strategy to modulate the depth of storage (Fig. 2).

\subsection{Generation of biogas: anaerobic digestion}

The biogas is produced by anaerobic decomposition of organic matter by methanogenic bacteria, the key parameters of this process being the composition of organic matter used [71] and temperature on the digester, either mesophilic $\left(30-35{ }^{\circ} \mathrm{C}\right)$ or thermophilic $\left(55{ }^{\circ} \mathrm{C}\right)$ $[54,67]$. The amount of biogas produced, as well as its composition, will depend to a large extent on the organic matter or substrate used, requiring an adequate balance between the $\mathrm{C}$ and $\mathrm{N}$ content into the substrate (Wu et al., 2009). On average, it is estimated that 300-1000 L of biogas per $\mathrm{kg}$ of fermentable volatile solids [15] can be produced, varying the hydraulic residence time of the biomass in the anaerobic reactor between 10 and 30 days depending on its greater or lesser biodegradability [51]. The biogas produced usually has a $\mathrm{CH}_{4}$ content of $56.7 \%$ and $63.5 \%[61,40]$, although this proportion can increase up to $80 \% \mathrm{CH}_{4}$ if really easily degradable substrates and optimum conditions are used.

The production of biogas in anaerobic digesters operated between 30 and $35{ }^{\circ} \mathrm{C}$ ranged at 0.5 to $4.0 \mathrm{~L}$ per litre of reactor and day depending on the quality of the substrate used, which corresponds to net methane production rates between 0.2 and $2.4 \mathrm{~L} / \mathrm{L}$-day. If the temperature decreases below $20{ }^{\circ} \mathrm{C}$, this production of biogas is significantly reduced, while in the thermophilic range the production 


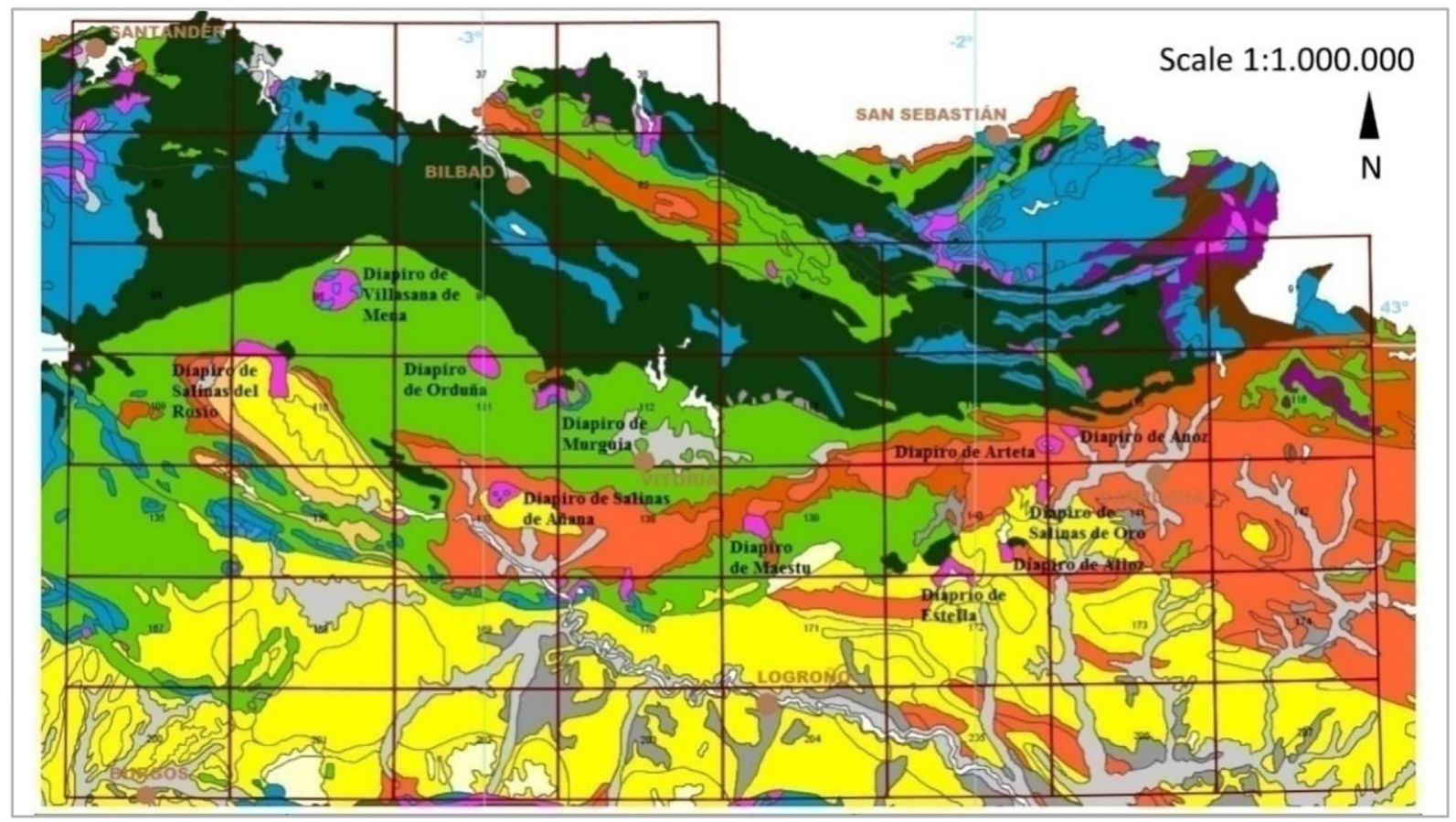

Fig. 2. Basin Basque-Cantabrian, as a region of development of the concept mini-CAES and bio-CAES [42].

increases [40,23] up to $40 \%$ [37]. Another option to increase biogas production is the application of pre-treatment techniques [7] such as thermal hydrolysis step before anaerobic digestion, which increases the production of methane between 30 and $52 \%$ [66].

For the current study, the production of biogas in the mesophilic range has been considered. To determine the dimensions of the digester required for a biogas production of between $120-200 \mathrm{~m}^{3} / \mathrm{h}$, it is considered the utilization of a substrate with an organic matter content of $40-60 \mathrm{~g} / \mathrm{L}$, in the range of conventional anaerobic digestion processes [1]. Substrates accomplishing this requirement include wastes produced in the primary sector (straw form cereals, grass ensilage, leaves and cattle and pig manure). In order to minimize the heat losses into the system, the walls of the digester shall be insulated with a polymer layer; according to previous works published polystyrene could be used [15].

\subsection{Use of biogas: Combined heat and power unit}

For the energy use of biogas, a Combined Heat and Power (CHP) system is considered [38,65]. Chemical energy is transformed into electricity and heat, where fuel options included biogas and other biobased liquids and gases [55]. CHP system comprise internal combustion engine and an electric generator. Additionally, this system takes advantage of the thermal energy generated through heat exchangers with the different thermal fluids of the engine: specifically, engine cooling systems and exhaust gas systems.

Electricity production may be determined according to electrical efficiency which is defined as the ratio between produced energy (power) and heat of combustion (calorific value). Electrical efficiency $\left(\mu_{\mathrm{e}}\right)$ assessment is based on the commercial specifications of a generator with biogas as fuel, and its value is 0.4277 [60]. In particular, the energy balances of the engine reflect that the chemical energy of the biogas is transformed following the following scheme: (i) electricity: $42.77 \%$ and (ii) theoretically, the rest of the heat of combustion is transformed into thermal energy, $57.23 \%$. Thermal energy is distributed into different gen-set equipment: Jacket water heat (HT), $23.10 \%$. Intercooler (LT) water heat, $2.45 \%$. Exhaust heat, $21.02 \%$, engine radiation heat, $2.96 \%$ and generator radiation heat, $1.23 \%$. In this case, to achieve the best organization in the use of heat, it is recommended to use the thermal energy of the cooling water of the engine jacket and that of the exhaust gases [16].

Thus, thermodynamic calculations for the heat transfer process from the biogas gen-sets to the expansion process are based on the consideration of adiabatic heat exchangers. This exchanger considers that the heat released by the hot fluid $\left(Q_{r}\right)$ is equal to the heat absorbed by the cold fluid $\left(\mathrm{Q}_{\mathrm{a}}\right)$ [48]. Taken into account the calorific capacity of the considered fluid $\left(\mathrm{C}_{\mathrm{Pr}}, \mathrm{C}_{\mathrm{Pa}}\right)$, it is possible to establish the transmitted heat as a function of mass flow of fluids $\left(\mathrm{m}_{\mathrm{r}}, \mathrm{m}_{\mathrm{a}}\right)$ and temperature variations $\left(\Delta \mathrm{T}_{\mathrm{r}}, \Delta \mathrm{T}_{\mathrm{a}}\right)$ (Eq. (2)). This equation will be applied according to the number of exchangers defined in the expansion stage.

$m_{r} \hat{\mathrm{A}} \cdot C p_{r} \hat{\mathrm{A}} \cdot \Delta T_{r}=m_{a} \hat{\mathrm{A}} \cdot C p_{a} \hat{\mathrm{A}} \cdot \Delta T_{a}$

Eq. (2). Transmitted heat in adiabatic exchangers in the CHP unit.

\subsection{Expansion process}

In the process of expanding the compressed air from the underground conditions $\left(\mathrm{P}_{\mathrm{i}}, \mathrm{T}_{\mathrm{i}}\right)$ to the final stage $\left(\mathrm{P}_{\mathrm{f}}, \mathrm{T}_{\mathrm{f}}\right)$ in its release into the atmosphere, an enthalpy change occurs with two effects: work $\left(\mathrm{W}_{\mathrm{if}}\right)$ and, drop in air temperature according to its expansion process. Both variations are relevant in this study, since from its calculation it will be possible to know the energy generated in the process that will be transformed into electrical energy through the turbine, and it will also be known in thermal exchange with the CHP system described.

Thus, thermodynamic calculation of the expansion process, according to [69], considers air as an ideal gas and the adiabatic process. Considering the Ideal Gas Law, and an isentropic coefficient of 1.40 $\left(C_{p} / C_{v}=k\right)$ [69], it is possible to assess the power of the process (Eq. (5)), considering the isentropic compression process (Eq. (3)) [6] and the first thermodynamic Law (Eq. (4)).

$\frac{T_{f}}{T_{i}}=\left(\frac{p_{f}}{p_{i}}\right)^{\frac{k-1}{k}}$

Eq. (3). Initial (pi, Ti) and final (pf, Tf) conditions, considering an isentropic compression process. 
$w_{i f}=\int_{i}^{f} v \hat{\mathrm{A}} \cdot d p$

Eq. (4). First thermodynamic Law.

$w_{i f}=\frac{k}{k-1} R T_{i}\left[\left(\frac{p_{f}}{p_{i}}\right)^{\frac{k-1}{k}}-1\right]$

Eq. (5). Power unit, considering an isentropic process and ideal gas.

\section{Results}

The alternative of an energy storage cavity at a depth of $100 \mathrm{~m}$ and of moderate dimensions of $20,000 \mathrm{~m}^{3}$ is considered in this study. In this way, anaerobic digestion is considered in the range of standard production, mesophilic conditions are the most widespread operation mode in industrial applications.

\subsection{Train of compression and heat exchanger}

According to the cavity conditions defined in material and methods section, the mass of air to be injected into the cavity is calculated with Eq. (6). Considering the most efficient train of compression, the same ratio of compression is considered for this calculation (Eq. (7)).

$\dot{m}=\frac{m(k g)}{t(s)}$

Eq. (6). Operative volume to be compressed and injected into the storage cavity

Considering maximum and minimum pressure conditions, it is possible to determine the flow of air to be injected into the cavity, named as working air. The flow could be assessed considering $6 \mathrm{~h}$ in the process of compression (Table 1 ).

The description of the compression train considers the Eq. (7) to define the number of stages and a similar ratio of compression for each stage $(\alpha)$. Finally, the work consumed in the compression train (W) might be assed according to Eq. (8). Where $n$ is number of stages, $P_{2}$ is the final pressure and $P_{1}$ is the initial pressure.

$\alpha=\sqrt[n]{\frac{P_{\text {max }- \text { cavity }}}{P_{\text {atm }}}}$

Eq. (7). Ratio of compression

$W=\int_{P 1}^{P 2} \frac{d P}{\rho}=\frac{n}{n-1} \frac{P_{1}}{\rho_{1}}\left[\left(\frac{P_{2}}{P_{1}}\right)^{\frac{n-1}{n}}-1\right]$

Eq. (8). Energy consumption, considering a polytrophic process.

In order to find the most efficient storage system that takes advantage of the maximum amount of available thermal energy from the compressed air, a sensitivity analysis has been carried out considering: (a) Compression stages; from 1 to 5 stages, (b) Water flows; from 5 to $40 \mathrm{~kg} / \mathrm{s}$, (c) Temperature of water outlet of the heat exchanger (air-water), from 65 to $95{ }^{\circ} \mathrm{C}$.

The value to be optimized is the energetic coefficient $(\Delta \varepsilon)$ (Eq. (9)). It is measured as the difference between the heat transmitted to the water (used by the same system, as "benefitted heat", $\mathrm{q}_{\mathrm{b}}$ ) and the heat that must be lost from the air to avoid excessively high temperatures (heat lost by the system, $\mathrm{q}_{1}$ ) divided by the benefitted heat or transmitted to water.

Table 1

Operational conditions of the air storage cavity.

\begin{tabular}{llll}
\hline & Pressure $(\mathrm{kPa})$ & Mass $(\mathrm{kg})$ & Flow $(\mathrm{kg} / \mathrm{s})$ \\
\hline Maximum storage conditions & 1,800 & 422,396 & \\
Minimum storage conditions & 900 & 211,198 & \\
Working air & & $\mathbf{2 1 1 , 1 9 8}$ & $\mathbf{9 , 7 7}$ \\
\hline
\end{tabular}

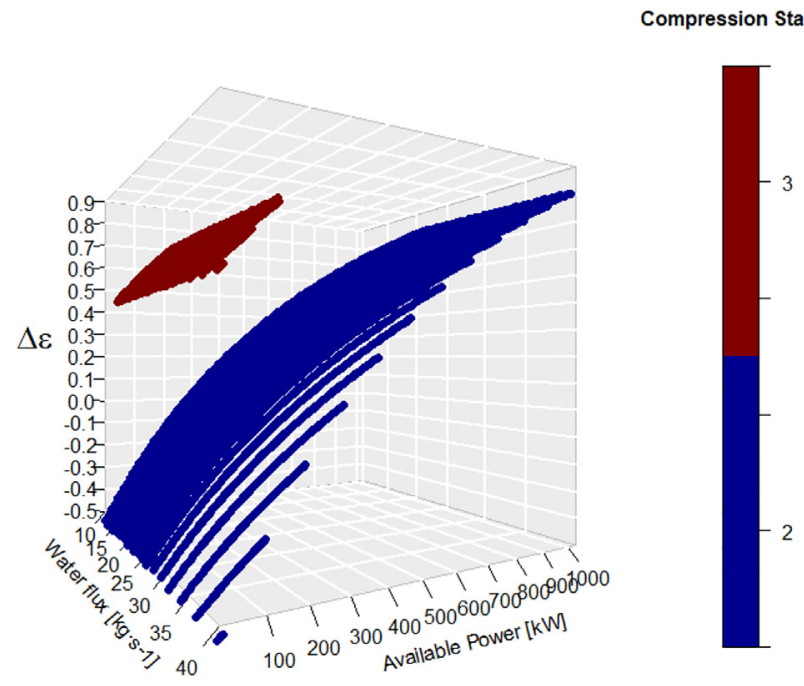

Fig. 3. Sensibility analysis considering different number of stages for the train of compression.

$\Delta \varepsilon=\frac{q_{b}-q_{l}}{q_{b}}$

Eq. (9). Energy coefficient of the BIOCAES system, measured as benefited heat.

It should be taken into account that the available air heat is the sum of the benefited heat $\left(\mathrm{q}_{\mathrm{b}}\right)$ plus the heat lost $\left(\mathrm{q}_{1}\right)$. The restriction of the analysis is that the benefitted heat " $\mathrm{q}_{b}$ " should be at least $33 \%$ of the available air heat then lost heat " $\mathrm{q}_{1}$ " should be $66 \%$ of the available heat that would result in a value of -1 and 1 when heat lost is zero. On the other hand, the usable power of the water defined as the available water power has been calculated from the power of $900 \mathrm{~kW}$ necessary to maintain the conditions of the digester. With this, values of zero for the variable Power Available satisfy the system while the rest is the volume increase capacity of the digester (Fig. 3).

According to the simulation process, four and five stages do not meet the aforementioned condition described in the previous paragraph. On the other hand, the best option to satisfy the $900 \mathrm{~kW}$ of the digester is a system with three compression stages.

Once the three compression stages have been chosen, it is necessary to consider different parameters to select the optimal operating conditions of the train of compression (Fig. 4).

\subsection{Anaerobic digestion: biogas production}

Considering a digester with a capacity of $5,000 \mathrm{~m}^{3}$ and a waste with organic matter concentration of $45-55 \mathrm{~kg}$ of organic matter per $\mathrm{m}^{3}$, it is possible to determine the production of biogas considering mesophilic conditions. Since the complete mix reactors are the digesters more prevalent, given that they can be fed with wide range of organic substrates (urban solids, manures, green wastes and others), this technology was chosen in this proposal. Reactor consists in a cylinder of $22 \mathrm{~m}$ of diameter and $11 \mathrm{~m}$ of height with a pneumatic cover shaped like spherical cap with a partial height of $4.1 \mathrm{~m}$. A complete description of this technology has been previously reported [15,62,59].

The overall volume of the digester is $5,000 \mathrm{~m}^{3}$. One quarter of this volume corresponds to the headspace which is occupied by biogas, according to the design described by [15], and the hydraulic retention time is fixed at 20 days. This digester can treat a volume of wastes of $200 \mathrm{~m}^{3}$ per day with a biogas productivity of $5,300 \mathrm{~m}^{3}$ of raw biogas. In this calculation a yield of $0.53 \mathrm{~m}^{3}$ of biogas per $\mathrm{kg}$ or organic matter was considered, taking an average value of main available wastes and the reported biogas production (Table 2) [15].

The anaerobic digester is integrated in the overall process using the 


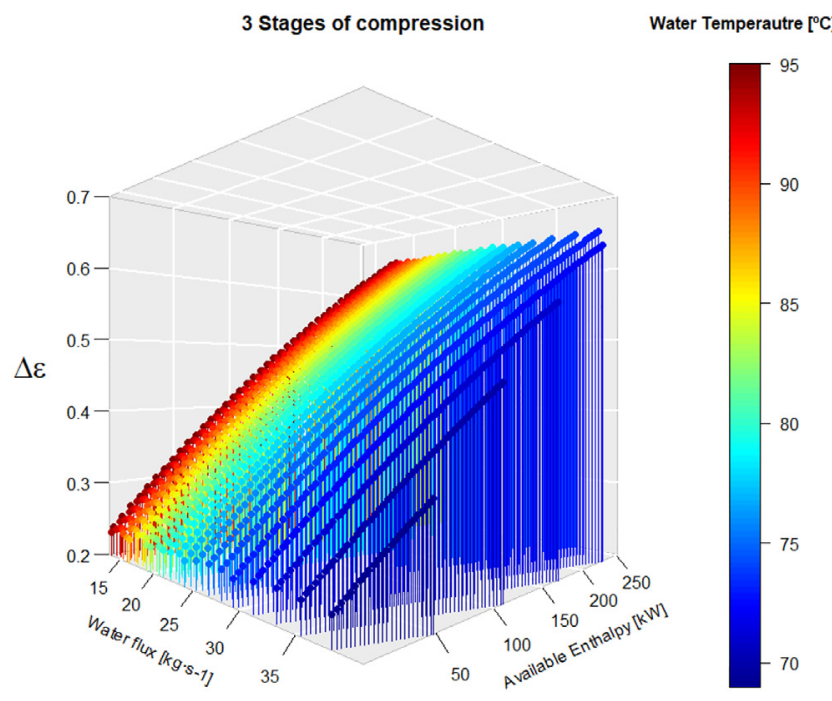

Fig. 4. Sensibility analysis considering four parameters: water temperature, water flux, available enthalpy and efficiency of the hybridization system.

Table 2

Biogas production considering the most common organic matter (mesophilic conditions).

\begin{tabular}{ll}
\hline Waste & Biogas production $\left(\mathrm{m}^{3} / \mathrm{kg}\right.$ organic matter $)$ \\
\hline Straw from cereals & $0.2-0.5$ \\
Grass ensilage & $0.6-0.7$ \\
Leaves & 0.6 \\
Vegetable wastes & 0.4 \\
Bio-waste from households & $0.1-0.3$ \\
Cattle Manure & $0.1-0.8$ \\
\hline
\end{tabular}

Table 3

Anaerobic Digestion parameters to define energy production.

\begin{tabular}{|c|c|c|}
\hline & Value & Units \\
\hline \multicolumn{3}{|l|}{ Digester dimensions } \\
\hline Volume & 5,000 & $\mathrm{~m}^{3}$ \\
\hline Height & 11 & $\mathrm{~m}$ \\
\hline Diameter & 22 & $\mathrm{~m}$ \\
\hline Height spherical cap & 4.1 & $\mathrm{~m}$ \\
\hline \multicolumn{3}{|l|}{ Digester operation } \\
\hline Hydraulic Retention Time & 20 & $\mathrm{~d}$ \\
\hline Flow & 200 & $\mathrm{~m}^{3} \mathrm{~d}^{-1}$ \\
\hline Biogas production & 5,300 & $\mathrm{~m}^{3} \mathrm{~d}^{-1}$ \\
\hline \multirow[t]{2}{*}{ Biogas composition } & $65 \% \mathrm{CH}_{4} / 35 \%$ & $\%$ vol \\
\hline & $\mathrm{CO}_{2}$ & \\
\hline Biogas yield & 0.53 & $\begin{array}{l}\mathrm{m}^{3} \text { biogas } \mathrm{kg} \\
\mathrm{SV}^{-1}\end{array}$ \\
\hline Organic matter concentration & $45-55$ & $\mathrm{Kg} \mathrm{SV} \mathrm{m}^{-3}$ \\
\hline \multicolumn{3}{|l|}{ Digester energy balance (daily basis) } \\
\hline Energy production (as biogas) & 34,450 & $\mathrm{kWh}$ \\
\hline Total Heat required & 5,214 & kWh \\
\hline Heat required (thermostatation digester) & 410 & $\mathrm{kWh}$ \\
\hline Heat required substrate & 4,702 & $\mathrm{kWh}$ \\
\hline
\end{tabular}

thermal energy released in the compression train. Operational parameters and main energy figures of the projected biogas installation are shown in Table 3.

Total heat required by the anaerobic process $\mathrm{Q}_{\mathrm{t}}$, (kWh per day) was calculated following the Eq. (10).

$Q_{T}=Q_{D}+Q_{S}$

Eq. (10). Total Heat required by the anaerobic process.

Where $Q_{D}$ is the thermal energy required to maintain the mesophilic temperature $\left(35{ }^{\circ} \mathrm{C}\right)$ in the inner part of the digester and $\mathrm{Q}_{s}$ is the thermal energy required to elevate the temperature of the inlet substrate from ambient temperature to $35{ }^{\circ} \mathrm{C}$. $\mathrm{Q}_{\mathrm{D}}$ was calculated as an addition of the total heat losses through the surface of the digester (Eq. (11)).

$Q_{D}=Q_{w}+Q_{c}+Q_{G}$

Eq. (11). Total Heat Losses.

Where $Q_{w}$ is the heat losses through the vertical wall of the cylinder, which is the thermal energy transferred from liquid content of the digester to the air. $\mathrm{Q}_{\mathrm{c}}$ is the heat losses through the pneumatic cover of the digester (biogas and air). $\mathrm{Q}_{\mathrm{G}}$ is the heat losses due to the heat transfer through the digester and the ground. The values of $Q_{w}, Q_{c}$ and $\mathrm{Q}_{\mathrm{g}}$ where calculated according to the Eq. (12).

$Q=U \cdot A \cdot\left(T_{i}-T_{0}\right)$

Eq. (12). Heat Losses in a partition of the digester.

Where $U\left(\mathrm{Wm}^{-2} \mathrm{C}^{-1}\right)$ is the heat transfer coefficient, $A\left(\mathrm{~m}^{2}\right)$ is the area of partition considered (walls, cover or ground), $\mathrm{T}_{\mathrm{i}}$ is the temperature inside the digester $\left(35^{\circ} \mathrm{C}\right)$ and $\mathrm{T}_{\mathrm{o}}$ is average ambient temperature. Heat transfer coefficient $(U)$ was calculated following the suggestion of PN-EN ISO 6946 (Eq. (13)).

$U=\frac{1}{R_{i}+\sum_{i=1}^{n} \frac{d_{i}}{k_{i}}+R_{o}}$

Eq. (13). Heat Transfer Coefficient

Where $R_{i}$ and $R_{o}$ are the resistance of the heat transfer through the inner and outer surface of the digester. $d$ is the thickness of the material layer used in the insulation and $k$ is the thermal conductivity coefficient of this material (polystyrene). A value of $k$ of $0.05 \mathrm{Wm}^{-1} \mathrm{C}^{-1}$ was considered in this study. The heat transfer coefficients inside and outside the reactor were 4,000 and $400 \mathrm{Wm}^{-2} \mathrm{C}^{-1}$, respectively [15].

The amount of energy required to heat the substrate was calculated according to the Eq. (14).

$Q s=F_{s} \cdot C_{H 20} \cdot\left(T_{i}-T_{i}\right)$

Eq. (14). Energy required to heat the substrate.

Where, $F_{s}$ is the daily influent flow to the digester $\left(\mathrm{m}^{3} \mathrm{~d}^{-1}\right), \mathrm{C}_{\mathrm{H} 2 \mathrm{O}}$ is the heat capacity of the water (which is assumed to be equal to the heat capacity of the substrate since it is composed in $96 \%$ per water).

The amount of thermal energy required by the anaerobic digestion was estimated in 5,214 kWh per day. Compression train can supply a total of $5,400 \mathrm{kWh}$ in each cycle of compression (one per day), enough energy to supply the thermal needs of the digester, so no supplemental thermal energy is required to thermostatationthe digester and substrates. These conditions present a significantly more favourable scenario for waste conversion to energy through anaerobic digestion, since conventional processes consume an important amount of biogas in boilers. This fact jeopardizes the implementation of digesters in temperate or cold climates where thermal demand account with a large contribution of the energy production in installations devoted to management of manure, green waste or other residues [24,57]. Beside this, integration of biogas production units into the renewable mix has been pointed out as an important tool for production of indigenous decarbonized energy [35].

Taking into consideration the Basque-Cantabrian Basin as a case of study, it has been considered the data from PROBIOGAS project to determine the availability of organic matter substrates referred in Table 2 [56]. As shown in Fig. 5, the Basque-Cantabrian region produces enough organic waste which could be considered as a raw material in the BIO-CAES system. The area includes several agro-industries (livestock: pig and cattle farming and related industries). Geological conditions would define the location of the BIO-CAES infrastructure, but it should be far from urban areas. For this reason, Organic Matter considered in this study were based on industrial waste such as agroindustry (livestock farming, crop residues).

Fig. 5 represents available organic matter from industry (residues), 


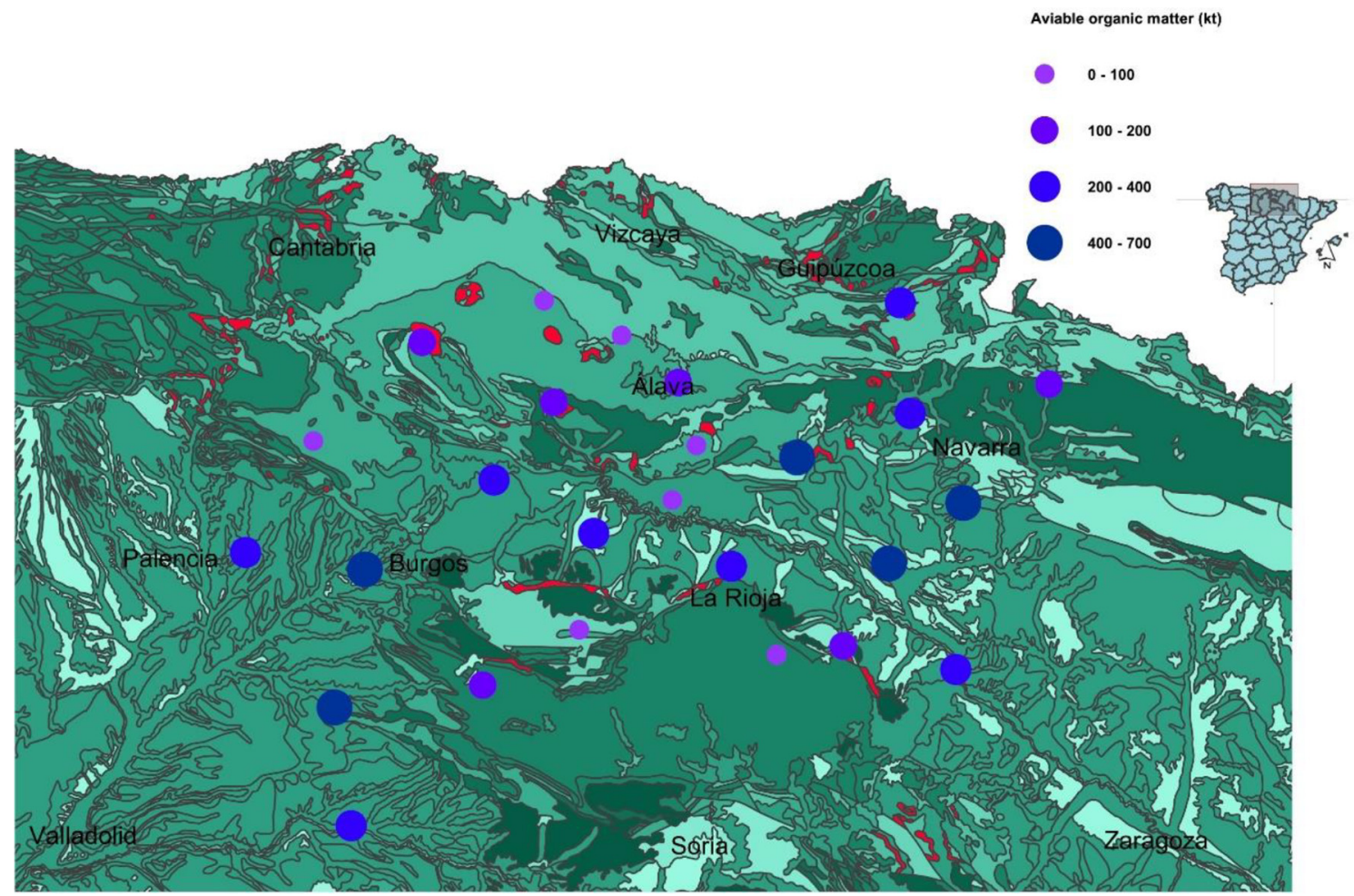

Fig. 5. Available Organic Matter. Area of study: Basque-Cantabrian Basin.

whereas red areas represent salt dome structures. According to this figure, Basque-Cantabrian basin could be a suitable region to consider a BIO-CAES infrastructure to store energy. Most of the geological structures considered are close to industrial residues (with a local capacity higher than required for the BIO-CAES system described in this study).

\subsection{Biogas CHP}

The calculation of the CHP system will be carried out for the case of biogas production in the mesophilic range. The general scheme of operation is as follows: Although the temperature of the inlet air to the geological storage is higher than that of the cavity, due to the high thermal transmission that occurs in this type of storage, it is reasonable to consider that the air temperature is going to equal quickly to that of storage, which for a depth of $100 \mathrm{~m}$ can be estimated at $18{ }^{\circ} \mathrm{C}$ (Considering a normal Geothermal Gradient, $25{ }^{\circ} \mathrm{C} / \mathrm{km}$ ).

As it can be seen from the comparison of points 9 (jacket water) and 15 (exhaust gases) points (Fig. 6), the exergetic value of the combustion gasses is much higher than the jacket water, since its temperature is much higher (Table 4). Therefore, its ability to raise the temperature of the air which is extracted from the storage cavity is higher, despite being different fluids. Therefore, and for a greater thermal utilization and a greater overall efficiency of the assembly, in each one of the planned turbine stages, it is proposed to first perform a thermal exchange between the air to be expanded and the jacket water (preheating) for later increase its enthalpy in another thermal exchange of the air with the exhaust gasses. The configuration considered in this study is the most efficient from the thermal energy point of view.

Moreover, Fig. 6 represents the study based on heat transfer, thus the pressure on the water and flue gases circuits have been considered constant: 2 and 1.5 bar respectively.

Regarding the electrical generation through the alternator coupled to the combustion engine, the calculation starts from the data provided regarding the electrical performance of the whole, with respect to the inlet biogas flow and its calorific value. Taking into account the daily variations of the electricity price [50], and selecting the hours in which said price is higher, a generation period of four hours will be considered both for the motor generator and for the compressed air expansion turbine, since they must work simultaneously to be able to carry out the thermal exchanges between the different fluids. According to the proposed scheme (Fig. 6) and taking into account the Eq. (2), the results collected in the table are obtained (Table 4).

For the estimation of electricity generation, the gen-set performance is considered in the equipment specification described in 'materials and methods' section. With an electrical performance of $42.77 \%$ and knowing the calorific value of the biogas $\left(7.02 \mathrm{kWhm}^{-3}\right)$, and the daily production $\left(5,300 \mathrm{~m}^{3} \cdot \mathrm{day}^{-1}\right)$, the energy of the biogas (primary energy of the process) is obtained: $37,206 \mathrm{kWh}$. Finally, the final electricity produced will be $15,912 \mathrm{kWh}_{\mathrm{e}}$ day $^{-1}$. With the operating regime established ( $4 \mathrm{~h}$ per day) the final power of the motor generator will be $3.98 \mathrm{MW}_{\mathrm{e}}$.

Considering the values obtained in Table 4 and Eq. (2), it is possible to calculate the used heat from the CHP system, reaching energy values of $8,506 \mathrm{kWh}$ from the jacket water and $7,822 \mathrm{kWh}$ from the exhaust gases (total used heat is $16,328 \mathrm{kWh}$ ). If these values are compared with those of the heat available (8.593 $\mathrm{kWh}$ and $8,226 \mathrm{kWh}$ respectively, total heat available $16,819 \mathrm{kWh}$ ), the overall efficiency of the system is $97.08 \%$ (ratio between used heat and available heat). It suggests that the utilization of the available heat is practically the maximum.

To confirm the values obtained, it should be verified that the heat transmission in the preheating stage - which is limited by the exit temperature of the water from the jacket water $90{ }^{\circ} \mathrm{C}$ and by the first principle of thermodynamics-, reaches reasonable values. Thus, the temperature of air in the preheating step is below $85^{\circ} \mathrm{C}$. In both cases (points 2 and 5, Fig. 6), the temperature is really below with values close to $82{ }^{\circ} \mathrm{C}$, validating these calculations.

It must also be confirmed that the temperature of the compressed air does not drop below $0{ }^{\circ} \mathrm{C}$ after the expansion process (points 4 and 7 , Table 4 and Fig. 6) to avoid possible freezing of the humidity of the air. This could limit the use of heat from exhaust gases, but this is not the case since the values are 2.08 and $1.03{ }^{\circ} \mathrm{C}$ respectively. Finally, the maximum temperatures reached for compressed air before entering the 


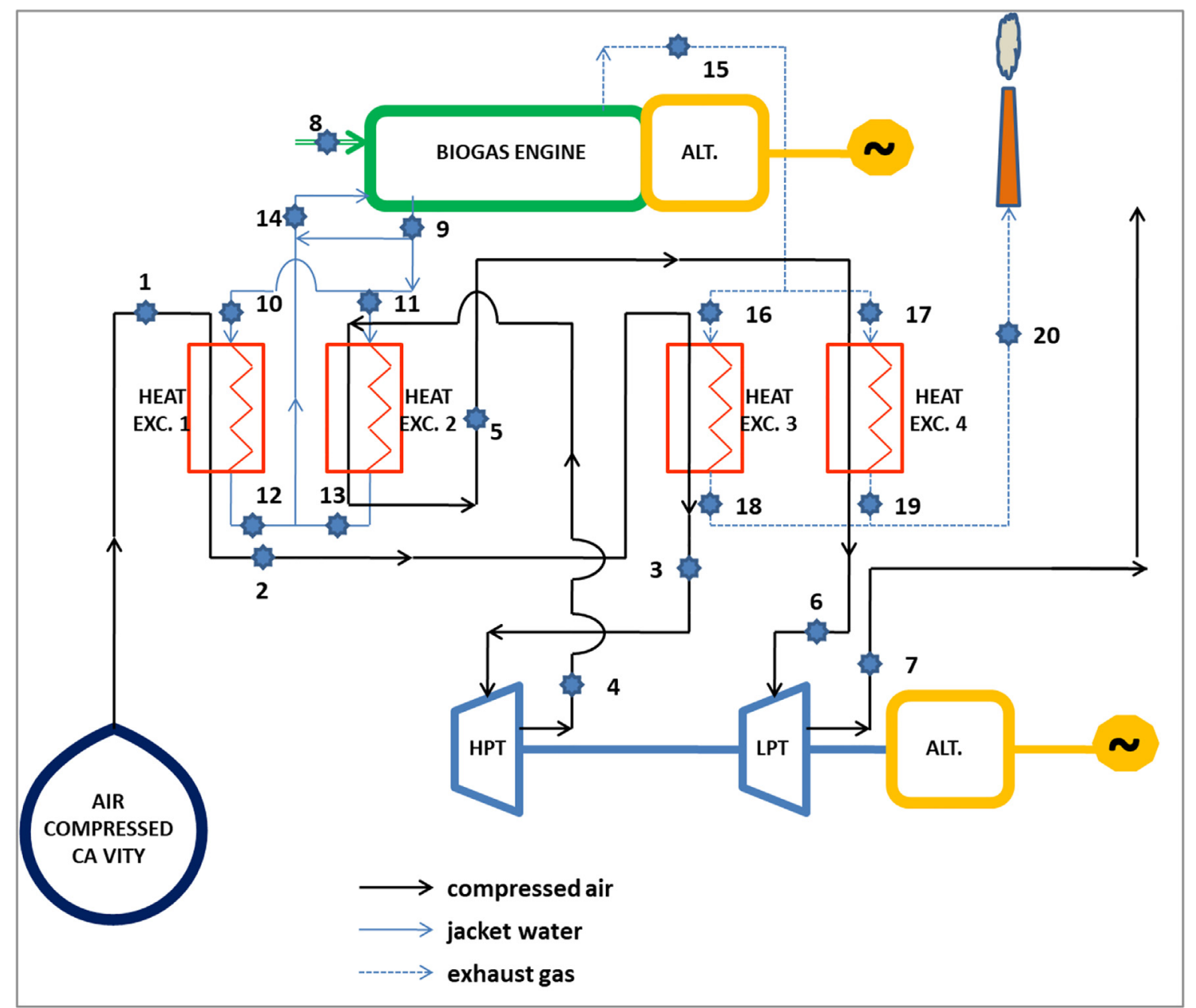

Fig. 6. Electricity generation system, considering CHP and HP \&LP turbines.

Table 4

CHP Heat Exchange.

\begin{tabular}{lllll}
\hline Point & Fluid & Temp. ${ }^{\circ} \mathrm{C}$ & Flow & \\
\hline 1 & air & 18 & 14.66 & $\mathrm{~kg} / \mathrm{s}$ \\
2 & air & 82.52 & 14.66 & $\mathrm{~kg} / \mathrm{s}$ \\
3 & air & 145.15 & 14.66 & $\mathrm{~kg} / \mathrm{s}$ \\
4 & air & 2.08 & 14.66 & $\mathrm{~kg} / \mathrm{s}$ \\
5 & air & 80.93 & 14.66 & $\mathrm{~kg} / \mathrm{s}$ \\
6 & air & 143.56 & 14.66 & $\mathrm{~kg} / \mathrm{s}$ \\
7 & air & 1.03 & 14.66 & $\mathrm{~kg} / \mathrm{s}$ \\
8 & biogas & 15 & 1,325 & $\mathrm{~m}^{3} / \mathrm{h}$ \\
9 & water & 90 & 118.04 & $\mathrm{~m}^{3} / \mathrm{h}$ \\
10 & water & 90 & 53.12 & $\mathrm{~m}^{3} / \mathrm{h}$ \\
11 & water & 90 & 64.92 & $\mathrm{~m}^{3} / \mathrm{h}$ \\
12 & water & 74.50 & 53.12 & $\mathrm{~m}^{3} / \mathrm{h}$ \\
13 & water & 74.50 & 64.92 & $\mathrm{~m}^{3} / \mathrm{h}$ \\
14 & water & 44.50 & 118.04 & $\mathrm{~m}^{3} / \mathrm{h}$ \\
15 & exhaust gases & 440 & 19,752 & $\mathrm{~m}^{3} / \mathrm{h}$ \\
16 & exhaust gases & 440 & 9,876 & $\mathrm{~m}^{3} / \mathrm{h}$ \\
17 & exhaust gases & 110 & 9,876 & $\mathrm{~m}^{3} / \mathrm{h}$ \\
18 & exhaust gases & 110 & 9,876 & $\mathrm{~m}^{3} / \mathrm{h}$ \\
19 & exhaust gases & 110 & 9,876 & $\mathrm{~m}^{3} / \mathrm{h}$ \\
20 & exhaust gases & 19,752 & $\mathrm{~m}^{3} / \mathrm{h}$ \\
\hline
\end{tabular}

turbine (points 3 and 6, Table 4 and Fig. 6) below $150{ }^{\circ} \mathrm{C}$ are reasonable and compatible with the current materials used in the manufacture of radial turbines.

\subsection{Expansion process}

The expansion system consists of different stages in which the selected equipment is the radial turbine, $[26,49]$ to maximize the electrical energy generated through the expansion of compressed air in the CAES cavity [27]. In the case studied (Fig. 6), a High Pressure (HPT) and Low Pressure (LPT) Turbines are considered [25], on which previous air heating is carried out using the heat generated by the CHP system [12], to increase the enthalpy of the air and improve the electrical performance of the assembly, which is the final objective of this study, as well as to demonstrate its viability.

For the calculation of the intermediate pressures, equal pressure jumps are considered in each of the stages, [18], where the intermediate pressure (point 4,) will determined with the Eq. (7). Finally, ambient pressure is the final pressure of the entire system. The following results are obtained from the calculations made based on the compressed air data and its different heating in the CHP system (Table 5).

The results obtained, in this case, are defined by the generation of electrical energy by the set of radial expansion turbines. In an engineering scheme, both groups of turbines will be coupled to a common axis that will turn an alternator to generate electric power. In this study we do not consider the mechanical losses of this equipment, which are usually not very significant [69]. Therefore, we can show the general energy by the HPT and by the LPT in a differentiated way, which allows us to obtain more information. Taking into account this simplification, this mechanical work obtained in the process can be assimilated as electrical energy generated, obtaining the final data of electric 
Table 5

Compressed air expansion process.

\begin{tabular}{lllll}
\hline Point & Fluid & Temperature $\left({ }^{\circ} \mathrm{C}\right)$ & Pressure (bar) & Flow (kg/s) \\
\hline 1 & air & 18.00 & 17.82 & 14.66 \\
2 & air & 82.52 & 17.82 & 14.66 \\
3 & air & 145.15 & 17.82 & 14.66 \\
4 & air & 2.08 & 4.22 & 14.66 \\
5 & air & 80.93 & 4.22 & 14.66 \\
6 & air & 143.56 & 4.22 & 14.66 \\
7 & air & 1.03 & 1.00 & 14.66 \\
\hline
\end{tabular}

Table 6

Expansion turbines electrical power.

\begin{tabular}{lllc}
\hline Turbine group & HPT & LPT & TOTAL \\
\hline Power (MWe) & 2.07 & 2.06 & 4.13 \\
\hline
\end{tabular}

generation in the expansion system (Table 6). Taking into consideration, the electric generation values obtained in the CHP system, a total joint generation in the environment of $8 \mathrm{MW}_{\mathrm{e}}$ is achieved.

\section{Conclusions}

The continuous increase in the installation of intermittent renewable energy supply systems (wind and solar energy) on detriment of energy supply systems based on fossil fuels, makes necessary to establish energy storage technologies that allow decoupling the generation and demand of energy. The development of energy storage systems is considered relevant for the deployment of the aforementioned energy sources.

Conventional Compressed Air Energy Storage System shows a low energy efficiency, compared to other alternatives such as Pumped Hydroelectric Storage. To overcome this issue, thermal energy produced in the compression stage may be managed coupled with an Anaerobic Digester.

Accordingly, a small underground cavity has been proposed $-100 \mathrm{~m}$ deep and a capacity of $20,000 \mathrm{~m}^{3}$ ) - to store compressed air. The process is driven by a three stage train of compression (20.2MWh). Enough thermal energy is produced to operate an Anaerobic Digester $\left(5,000 \mathrm{~m}^{3}\right.$ and an energy production of $\left.34.45 \mathrm{MWh} \cdot \mathrm{day}^{-1}\right)$; thus, the thermal energy is used instead of storage it, to produce biogas which easy stored. Biogas and compressed air is used in the process to produce energy - considering a Combined Heat and Power Unit, with an energy production of $15.91 \mathrm{MWh}_{\mathrm{e}}$ day $^{-1}$ and, $16.82 \mathrm{MWh}_{\text {thermal }} \cdot$ day $^{-1}$ and a train of turbines - Low and High Pressure, with an energy production of 16.52 $\mathrm{MWh}_{\mathrm{e}}$ day $^{-1}$. Therefore, the BIOCAES concept has a theoretical energy efficiency over $80 \%$.

The work of hybridization of technologies - anaerobic digestion and compressed air energy storage - gives undoubted benefits to the system: (1) sufficient thermal energy to work in the mesophilic range with the consequent stability in biogas production and a complete conversion of biodegradable organic matter into biogas; (2) energy storage in chemical form (biogas) more efficient than thermal energy storage; BIOCAES technology avoid any investment in expensive Thermal Energy Storage equipment; (3) the heat management in the BIOCAES technology, allows a high energy efficiency of the system, without heat losses; it has been assessed an overall theoretical efficiency of the BIOCAES higher than $70 \%$, which could be the figure considered for PHS system. (4) The use of gen-sets and biogas in periods of maximum demand for electricity, maximizes the return on investment of this system and finally, (5) BIO-CAES will be based on $100 \%$ renewable sources in the expansion process (generation of electricity), and it may be considered a secure source of energy.

Different compression and expansion configurations have been studied, proposing the one that offers the greatest efficiency of the whole, studying different configurations through calculation and simulation. The biochemical storage of the energy stored in the compressed air makes it possible to uncouple it completely from the electric power generation system through the generator-set system plus the compressed air turbine.

Next studies will evaluate socio-economic conditions in the BasqueCantabrian basin and region, in order to complete the hybridization technology description presented in this study.

\section{CRediT authorship contribution statement}

Bernardo Llamas: Conceptualization, Methodology, Writing - original draft, Writing - review \& editing, Project administration. Marcelo F. Ortega: Methodology, Investigation, Formal analysis. Gabriel Barthelemy: Investigation, Formal analysis. Ignacio de Godos: Investigation, Formal analysis. F. Gabriel Acién: Investigation, Methodology, Formal analysis, Validation.

\section{Declaration of Competing Interest}

The authors declare that they have no known competing financial interests or personal relationships that could have appeared to influence the work reported in this paper.

\section{References}

[1] Al Seadi, T. (2001). Good practice in quality management of AD residues from biogas production, Report made for the International Energy Agency, Task 24 Energy from Biological Conversion of Organic Waste. Published by IEA Bioenergy. Available from: http://www.iea-biogas.net.

[2] Aneke M, Wang M. Energy storage technologies and real life applications - a state of the art review. Appl Energy 2016;179:350-77.

[3] Antonelli M, Desideri U, Giglioli R, Paganucci F, Pasini G. Liquid air energy storage: a potential low emissions and efficient storage system. Energy Procedia 2016;88:693-7.

[4] Al Ayad M, Jubori Qusay A, Jawad. Investigation on performance improvement of small scale compressed-air energy storage system based on efficient radial-inflow expander configuration. Energy Convers Manage 2019;182:224-39.

[5] Banks CJ, Chesshire M, Heaven S, Arnold R. Anaerobic digestion of source-segregated domestic food waste: performance assessment by mass and energy balance. Bioresour Technol 2011;102(2):612-20.

[6] Barbour E, Mignard D, Ding Y, Li Y. Adiabatic Compressed Air Energy Storage with packed bed thermal energy storage. Appl Energy 2015;155:804-15.

[7] Bharathiraja B, Sudharsana T, Jayamuthunagai J, Praveenkumar R, Chozhavendhan S, Iyyappan J. Biogas production - a review on composition, fuel properties, feedstock and principles of anaerobic digestion. Renew Sustain Energy Rev 2018:90:570-82.

[8] Bilgili F, Koçak E, Bulut Ü. The dynamic impact of renewable energy consumption on CO2 emissions: a revised environmental Kuznets Curve Approach. Renew Sustain Energy Rev 2016;54:838-45.

[9] Braber K. Anaerobic digestion of municipal solid waste: a modern waste disposal option on the verge of breakthrough. Biomass Bioenergy 1995;9(1-5):365-76.

[10] Budt M, Wolf D, Span R, Yan J. A review on compressed air energy storage: basic principles, past milestones and recent developments. Appl Energy 2016:170:250-68.

[11] Chen H, Cong Y, Yang W, Tan C, Li Y, Ding Y. Progress in electrical energy storage: a critical review. Prog Nat Sci 2009;19(3):291-312.

[12] Chen X, Zhang T, Xue X, Chen L, Li Q, Mei S. A solar-thermal-assisted adiabatic compressed air energy storage system and its efficiency analysis. Appl Sci 2018;8:1390.

[13] Crotogino F, Mohmeyer K, Scharf R. (2002). Huntorf CAES: more than twenty years of successful operation. In: Solution mining research institute meeting, Orlando.

[14] Davis L, Schainker R. (2006) Compressed Air Energy Storage (CAES): Alabama electric cooperative McIntosh plant overview and operational history. In: Electricity storage association meeting: energy storage in action, Knowville.

[15] Deublin D, Steinhauser A. (2008), Biogas from waste and renewable resources: An introduction; Wiley -VCH- Verlag, Weinheim.

[16] Diyoke C, Aneke M, Wang M, Wu C. Techno-economic analysis of wind power integrated with both compressed air energy storage (CAES) and biomass gasification energy storage (BGES) for power generation. RSC Adv 2018;8:22004.

[17] Dogan E, Seker F. Determinants of $\mathrm{CO}_{2}$ emissions in the European Union: The role of renewable and non-renewable energy. Renewable Energy 2016;94:429-39.

[18] DreiBigacker V. Power-to-heat in adiabatic compressed air energy storage power plants for cost reduction an increased flexibility. Heat Mass Transfer 2018;54:955-62.

[19] Dreißigacker V, Belik S. System configurations and operational concepts for highly 
efficient utilization of power-to-heat in A-CAES. Appl Sci 2019;9:1317.

[20] European Council Report. http://www.consilium.europa.eu/uedocs/cms data/ docs/pressdata/en/ec/145397.pdf, 2014.Accessed on 18th of February 2019.

[21] European Environment Agency, EEA. Trends and Projections in Europe, 2018. 2018. https://www.eea.europa.eu//publications/trends-and-projections-in-europe2018-climate-and-energy, Access on 14th of February 2019.

[22] EUROSTAT: https://ec.europa.eu/eurostat/statistics-explained/index.php/ Electricity_production,_consumption_and_market_overview\#Electricity_generation, Access on 10th of February 2019.

[23] Fernández-Rodríguez J, Pérez M, Romero LI. Comparison of mesophilic and thermophilic dry anaerobic digestion of OFMSW: Kinetic analysis. Chem Eng J 2013;232:59-64.

[24] Fjørtoft K, Morken J, Hanssen JF, Briseid T. Methane production and energy evaluation of a farm scaled biogas plant in cold climate area. Bioresour Technol 2014;169(2014):72-9.

[25] Garrison JB, Webber ME. An integrated energy storage scheme for a dispatchable solar and wind powered energy system. J Renewable Sustainable Energy 2011;3:043101.

[26] He W, Wanga J, Ding Y. New radial turbine dynamic modelling in a low-temperature adiabatic compressed air energy storage system discharging process. Energy Convers Manage 2017;153:144-56.

[27] He W, Wang J. Optimal selection of air expansion machine y Compressed Air Energy Storage: A review. Renew Sustain Energy Rev 2018;87:77-95.

[28] Hemmati R, Saboori H. Emergence of hybrid energy storage systems in renewable energy and transport applications - A review. Renew Sustain Energy Rev 2016;65:11-23.

[29] Herout M, Malatak J, Kucera L, Diabaja T. Biogas composition depending on the type of plant biomass used. Res Agric Eng 2011;57(4):137-43.

[30] Hijazi O, Munro S, Zerhusen B, Effenberger M. Review of life cycle assessment for biogas production in Europe. Renew Sustain Energy Rev 2016;54:1291-300.

[31] Holm-Nielsen JB, Al Seadi T, Oleskowicz-Popiel P. The future of anaerobic digestion and biogas utilization. Bioresour Technol 2009;100(22):5478-84.

[32] Ibrahim H, Ilinca A, Perron J. Energy storage systems- characteristics and comparisons. Renew Sustain Energy Rev 2008;12:1221-50.

[33] IEA Energy Storage: https://www.iea.org/tcep/energyintegration/energystorage/, Access on 10th of February 2019.

[34] IEA Bioenergy report (2018). https://www.ieabioenergy.com/wp-content/ uploads/2018/04/green gas web_end.pdf Access on 30th September 2019.

[35] International Energy Agency. Key World Energy Statistics. Paris: France; 2018.

[36] Ito $\mathrm{K} . \mathrm{CO}_{2}$ emissions, renewable and non-renewable energy consumption, and economic growth: Evidence from panel data for developing countries. International Economics 2017;151:1-6.

[37] Kim JK, Oh BR, Chun YN, Kim SW. Effects of temperature and hydraulic retention time on anaerobic digestion of food waste. J Biosci Bioeng 2006;102(4):328-32.

[38] Kozak T, Majchrzycka A. Application of biogas for combined heat and power production in the rural region. (2009). West Pomeranian University of Technology. FMNS, Szczecin.

[39] Kyriakopoulos GL, Arabatzis G. Electrical Energy storage systems in electricity generation: energy policies, innovative technologies, and regulatory regimes. Renew Sustain Energy Rev 2016;56:1044-67.

[40] Labatut RA, Angenent LT, Scott NR. Conventional mesophilic vs, thermophilic anaerobic digestion: a trade-off between performance and stability? Water Res 2014;53:249-58.

[41] Llamas B, Laín C, Castañeda MC, Pous J. Multi-criteria algorithm-based methodology used to select suitable domes for compressed air energy storage. Int J Energy Res 2017;41(14):2108-20

[42] Llamas B, Laín C, Castañeda MC, Pous J. Study of the Basque-Cantabrian basin as a suitable region for the implementation of an energy storage system based on compressed air energy storage (CAES). Environmental Earth 2017;76:204.

[43] Llamas B, Laín C, Castañeda MC, Pous J. Mini-CAES as reliable and novel approach to storing renewable energy in salt domes. Energy 2019;144:482-9.

[44] Locatelli G, Palerma E, Mancini M. Assessing the economics of large Energy Storage Plants with an optimisation methodology. Energy 2015;83:15-28.

[45] Lora R, de Souza AM, da Fonseca FV, Sanchez A, Barrena R, Font X. Technology overview of biogas production in anaerobic digestion plants: A European evaluation of research and development. Renew Sustain Energy Rev 2017;80:44-53.

[46] Luo X, Wang J. (2013) Overview of current development on compressed air energy storage. EERA Technical Report. Warwick University.
[47] Luo X, Wang J, Dooner M, Clarke J. Overview of current development in electrical energy storage technologies and the application potential in power system operation. Appl Energy 2015;137:511-36.

[48] Luo X, Wang J, Krupke C, Wang Y, Sheng Y, Li J, et al. Modeling study, efficiency analysis and optimization of large-scale Adiabatic Compressed Air Energy Storage systems with low-temperature thermal storage. Appl Energy 2015;162:589-600.

[49] Luo X, Dooner M, He W, Wang J, Li Y, Li D, Kiselychnyk O. Feasibility study of a simulation software tool development for dynamic modelling and transient control of adiabatic compressed air energy storage with its electrical power system applications. Appl Energy 2018;228:1198-219.

[50] Market data. European Electricity Index (ELIX). https://www.epexspot.com/en/ market-data/elix/chart/index-chart/.

[51] Mao C, Feng Y, Wang X, Ren G. Review on research achievements of biogas from anaerobic digestion. Renew Sustain Energy Rev 2015;45:540-55.

[52] Mozayeni H, Negnevitsky M, Wang X, Cao F, Peng X. Performance study of an advanced adiabatic compressed air energy storage system. Energy Procedia 2017;110(2017):71-6.

[53] Ostergaard PA. Comparing electricity, heat and biogas storages' impacts on renewable energy integration. Energy 2012;37(1):255-62.

[54] Pagés-Díaz J, Westman J, Taherzadeh MJ, Pereda-Reyes I, SárváriHorváth I. Semicontinuous co-digestion of solid cattle slaughterhouse wastes with other waste streams: interactions within the mixtures and methanogenic community structure. Chem Eng J 2015;273:28-36.

[55] Pilavachi PA. Mini- and mico-gas turbines for combined heat and power. Appl Therm Eng 2002;22:2003-14.

[56] PROBIOGAS webpage: http://www.probiogas.es, access on 23rd of February 2019

[57] Pöschl M, Ward S, Owende P. Evaluation of energy efficiency of various biogas production and utilization pathways. Appl. Energy 2010;87(11):3305-21. https:// doi.org/10.1016/j.apenergy.2010.05.011.

[58] Razmi A, Soltani M, Torabi M. Investigation of an efficient and environmentallyfriendly CCHP system based on CAES, ORC and compression-absorption refrigeration cycle: Energy and exergy analysis. Energy Convers Manage 2019;195:1199-211.

[59] Sarker S, Lamb JJ, Hjelme DR, Lien KM. A Review of the Role of Critical Parameter in the Design and Operation of Biogas Production Plants. Appl. Sci. 1915;2019:9.

[60] SGE-H series gas engines and gen-sets biogas. SIEMENS. https://assets.new. siemens.com/siemens/assets/public.1532944303.

2513e5c2b20bd3aaaed8d8e005b5c34719f898e5.85296-sge-h-series-gasenginesbg-lr.pdf.

[61] Shi X, Guo X, Zuo J, Wang Y, Zhang M. A comparative study of thermophilic and mesophilic anaerobic co-digestion of food waste and wheat straw: Process stability and microbial community structure shifts. Waste Manage 2018;75:261-9.

[62] Teng Z, Hua J, Wang C, Lu X. Chapter 4-Design and optimization principles of biogas reactors in large scale applications A2-Shi, Fan. In Reactor and Process Design in Sustainable Energy Technology; Elsevier: Amsterdam, The Netherlands, 2014; pp. 99-134.

[63] Ubertini S, Facci AL, Andreassi L. Hybrid hydrogen and mechanical distributed energy storage. Energies 2017;10(12):2035.

[64] Vindis P, Mursec B, Janzekovic M, Cus F. The impact of mesophilic and thermophilic anaerobic digestion on biogas production. J Achiev Mater Manuf Eng 2009;36(2):192-8.

[65] Vögelin P, Georges G, Boulouchos K. Design analysis of gas engine combined heat and power plants (CHP) for building and industry heat demand under varying price structures. Energy 2017;125:356-66.

[66] Wang Q, Noguchi C, Hara Y, Sharon C, Kakimoto K, Kato Y. Studies on anaerobic digestion mechanism: influence of pretreatment temperature on biodegradation of waste activated sludge. Environ Technol 1997;18:999-1008.

[67] Wang X, Lu X, Li F, Yang G. Effects of Temperature and Carbon-Nitrogen(C/N) Ratio on the Performance of Anaerobic Co-Digestion of Dairy Manure. Focusing on Ammonia Inhibition: PLoS One, Chicken Manure and Rice Straw; 2014. p. 9.

[68] Weiland P. Production and energetic use of biogas from energy crops and wastes in Germany. Appl Biochem Biotechnol 2003;109(1-3):263-74.

[69] Wolf D, Budt M. LTA-CAES - A low temperature approach to Adiabatic Compressed Air Energy Storage. Appl Energy 2014;125:158-64.

[70] Zakeri B, Syri S. Electrical Energy Storage Systems: A comparative life cost analysis. Renew Sustain Energy Rev 2015;42:569-96.

[71] Zhang Q, Hu J, Lee DJ. Biogas from anaerobic digestion processes: research updates. Renewable Energy 2016;98:108-19. 